\title{
Fungsi Kognitif Lansia yang Beraktivitas Kognitif secara Rutin dan Tidak Rutin
}

\section{Cognitive Function of Elderly who Perform Frequent and Non- Frequent Cognitive Activities}

\author{
Adriana Dewi Riani',1 \& Magdalena S. Halim² \\ Magister Psikologi Profesi Universitas Katolik Indonesia Atma Jaya
}

\begin{abstract}
Ministry of Health Republic of Indonesia noted that $47 \%$ of the elderly in Indonesia still work. One of activity that the elderly might do is cognitive activity, such as watching news, reading books, art activities, and doing analytical things. Frequent cognitive activity is thought to preserve elderly cognitive function. This study aimed to see the comparison of cognitive function of elderly who perform frequent and nonfrequent cognitive activity. This was a quantitative study, based on 12 subtests of cognitive function as part of the Indonesian Neuropsychological Test Battery, to two elderly groups in Jakarta ( $\mathrm{N}=90,69$ women and 21 men), the elderly who performed frequent and non-frequent cognitive activities. The results indicated the presence of significant cognitive functional differences in all aspects of attention, language, and memory aspects except visual reproduction subtest and verbal learning (short term) subtest, among elderly groups who performed frequent and non-frequent cognitive activities. However, there was no significant difference in cognitive function in the executive function.
\end{abstract}

Keywords: frequent cognitive activity; cognitive function; elderly

\begin{abstract}
Abstrak. Kementerian Kesehatan RI mencatat bahwa 47\% dari jumlah lansia di Indonesia masih bekerja. Jenis aktivitas yang mungkin dilakukan lansia adalah aktivitas kognitif. Aktivitas kognitif yang rutin dilakukan diduga dapat mempertahankan fungsi kognitif lansia. Penelitian ini bertujuan untuk melihat perbandingan fungsi kognitif lansia yang beraktivitas kognitif secara rutin dan tidak. Penelitian ini merupakan penelitian kuantitatif, berdasarkan 12 subtes fungsi kognitif sebagai bagian dari baterai tes Neuropsikologi Indonesia, terhadap dua kelompok lansia di Jakarta (N=90, 69 perempuan, 21 laki-laki), yaitu lansia yang beraktivitas kognitif rutin dan tidak rutin. Hasil penelitian ini menunjukkan adanya perbedaan fungsi kognitif yang signifikan pada semua aspek atensi, bahasa, dan memori kecuali subtes visual reproduction dan verbal learning (short term), antara kelompok lansia yang rutin beraktivitas kognitif dan tidak rutin. Akan tetapi, tidak terdapat perbedaan fungsi kognitif yang signifikan pada fungsi eksekutif.
\end{abstract}

Kata kunci: aktivitas kognitif rutin; fungsi kognitif; lansia

${ }^{1}$ Korespondensi mengenai artikel ini dapat melalui: adriana.dewiriani@gmail.com 
Jumlah lansia di Indonesia akan semakin bertambah. Hal ini berdasar pada data yang dipaparkan oleh Kementerian Kesehatan Republik Indonesia (2016), bahwa setelah tahun 2100, populasi lansia di Indonesia akan menjadi lebih banyak daripada populasi lansia di dunia. Usia harapan hidup pun telah meningkat (Kementrian Kesehatan Republik Indonesia, 2016). Wreksoatmaja (2015) juga menyampaikan bahwa kemajuan pada bidang kedokteran dan kesehatan, berimbas pada peningkatan usia harapan hidup, dan tentunya jumlah penduduk berusia lanjut.

Menurut data dari Kemenkes RI, saat ini lansia masih dapat dikatakan lebih kuat secara fisik, karena $47 \%$ dari lansia di Indonesia masih bekerja. Data ini sekaligus menunjukkan bahwa hampir setengah dari lansia saat ini masih dapat melakukan aktivitas sehari-hari.

Aktivitas menurut Kamus Besar Bahasa Indonesia adalah keaktifan dan kegiatan (Kamus Besar Bahasa Indonesia, 2018). Aktivitas yang dilakukan lansia dapat dibagi menjadi aktivitas yang lebih banyak melibatkan fisik, dan aktivitas yang lebih banyak melibatkan kognisi, atau yang disebut dengan aktivitas kognitif. Kognisi mencakup proses untuk mengidentifikasi, memilih, mengartikan, menyaring, dan menggunakan informasi yang masuk akal (Johansson, 2015). Lezak, Howieson, Bigler, dan Tranel (2014) menyatakan bahwa terdapat empat kelas fungsi kognitif, yaitu fungsi penerimaan, fungsi memori dan pembelajaran, fungsi berpikir, dan fungsi ekspresif. Fungsifungsi ini pada akhirnya dapat diukur berdasarkan 4 aspek kognitif, yaitu atensi, memori, bahasa, dan fungsi eksekutif.

Wreksoatmaja (2015) menyampaikan bahwa aktivitas kognitif adalah aktivitas yang melibatkan kegiatan berpikir.
Beberapa aktivitas yang termasuk dalam aktivitas kognitif antara lain, memasak, menonton berita, membaca koran, bermain catur atau permainan yang mengasah otak (Wreksoatmaja, 2015), pekerjaan yang melibatkan kerja otak (Johansson, 2015), bermain puzzle, mengajar (Santrock, 2011), membuat kerajinan tangan, dan organisasi sosial (Geda, et al., 2011). Aktivitas kognitif dapat berupa aktivitas membaca koran, membaca buku, menonton berita, melakukan aktivitas atau kegiatan seni, serta kegiatan yang bersifat konsep, analisa, dan perencanaan.

Beberapa penelitian yang telah dilakukan sebelumnya menunjukkan hasil bahwa aktivitas kognitif dapat mempertahankan fungsi kognitif yang lebih baik pada lansia. Salah satunya penelitian Wreksoatmaja (2015) yang menghasilkan temuan bahwa lansia yang melakukan aktivitas kognitif, memiliki fungsi kognitif yang lebih baik daripada lansia yang tidak melakukan aktivitas kognitif. Geda et al. (2011) menyampaikan bahwa aktivitas-aktivitas kognitif yang dilakukan hanya pada saat waktu luang, tidak signifikan dalam meningkatkan fungsi kognitif seseorang. Asumsi ini juga didukung oleh penelitian Mella, Grob, Doll, Ghisletta, dan de Ribaupierre (2017), bahwa tidak terdapat hubungan antara kegiatan yang dilakukan lansia di waktu luang dengan performa kognitif lansia. Hal ini berarti bahwa aktivitas kognitif yang dapat mempertahankan fungsi kognitif pada lansia adalah aktivitas kognitif yang rutin dilakukan, tidak hanya dilakukan saat ada waktu luang saja.

Penelitian yang dilakukan Marquine, Segawa, Wilson, Bennett, \& Barnes (2012) menghasilkan temuan bahwa aktivitas kognitif yang dilakukan secara rutin, berkaitan secara umum dengan fungsi 
kognitif lansia yang lebih baik. Penelitian lain yang sejalan adalah penelitian yang dilakukan Lachman, Agrigoroaei, Murphy, dan Tun (2010). Dalam penelitian tersebut juga didapatkan hasil bahwa lansia yang terlibat dalam aktivitas kognitif secara regular, memiliki fungsi kognitif, khususnya pada aspek episodic memory yang lebih baik, meskipun pendidikan mereka rendah. Penelitian tersebut juga menunjukkan bahwa lansia yang berpendidikan rendah tetap dapat memiliki fungsi kognitif yang baik selama ia terlibat secara rutin dalam aktivitas kognitif.

Saat menua, terdapat penurunan fungsi pada lansia, termasuk fungsi kognitifnya. Dimensi kognitif yang dapat mengalami penurunan fungsi saat menua adalah kecepatan serta ketepatan dari proses berpikir yang berkaitan dengan penggunaan panca indera, atensi, memori motorik serta visual, fungsi pembedaan, perbandingan, dan kategorisasi (Santrock, 2011). Johansson (2015) juga menambahkan bahwa lansia akan mengalami penurunan juga dalam mempelajari halhal baru. Santrock (2011) juga menyampaikan bahwa lansia akan memilih informasi-informasi yang relevan baginya, karena mereka mulai mengalami kesulitan dalam mencerna informasi baru, apalagi dalam jumlah banyak.

Perubahan fungsi kognitif yang pasti akan terjadi pada lansia dapat berdampak pada meningkatnya frekuensi gangguan fungsi kognitif dan mental pada lansia, seperti demensia dan depresi (Haris, Steven, Handajani, 2014). Prevalensi dan insiden demensia maupun depresi tergolong cukup besar dengan pengeluaran biaya perawatan yang tidak sedikit. Di DKI Jakarta, prevalensi demensia dan depresi pada lansia mencapai $62,5 \%$ untuk demensia dan 30,1\% untuk depresi
(Handajani, dalam Haris, et al., 2014). Prevalensi demensia yang lebih dari 50\% menunjukkan bahwa kondisi kognitif para lansia, khususnya di Jakarta, cenderung belum terjaga dengan cukup baik dan penurunan fungsi kognitif cenderung lebih cepat terjadi pada lansia di Jakarta. Kondisi ini juga menunjukkan bahwa perlu dilakukan pemeliharaan fungsi kognitif pada lansia agar penurunan fungsi kognitif dapat tertunda.

Pemeliharaan fungsi kognitif pada lansia menjadi hal yang sangat penting untuk kesejahteraan lansia. Aktivitas kognitif yang dilakukan secara rutin diduga dapat mempertahankan fungsi kognitif yang prima pada lansia. Oleh karena itu, hal ini perlu dibuktikan dengan menguji perbedaan fungsi kognitif pada kelompok lansia yang melakukan aktivitas kognitif secara rutin dan tidak rutin. Selain itu, melalui penelitian ini juga akan diketahui aspek kognitif yang masih baik dan kurang pada kedua kelompok lansia. Hal ini dapat menjadi masukan juga bagi intervensi yang akan dirancang bagi kedua kelompok lansia.

\section{Metode}

Penelitian ini merupakan penelitian kuantitatif, dengan desain penelitian komparatif non-eksperimental. Variabel pada penelitian ini terdiri dari aktivitas kognitif rutin atau tidak rutin (independent variable) dan fungsi kognitif (dependent variable).

Pendekatan pengambilan sampel pada penelitian ini adalah non-probability sampling, dengan teknik convenience sampling. Partisipan penelitian ini terdiri dari dua kelompok lansia, dengan kriteria umum sebagai berikut, individu berusia di atas 60 tahun, sehat secara mental dan fisik, tidak sedang menderita penyakit 
kronis (stroke, diabetes berat, dan kanker), tidak mengalami katarak atau gangguan penglihatan, masih dapat membaca dengan atau tanpa kacamata, pendidikan minimal SMP/SLTP. Sementara itu, kriteria khusus untuk kelompok lansia yang melakukan aktivitas kognitif secara rutin adalah melakukan aktivitas kognitif secara rutin, aktivitas tersebut termasuk organisasi sosial, pekerjaan yang bersifat konsep, permainan mengasah otak, kegiatan seni, membaca koran, menonton berita. Selain itu, aktivitas tersebut harus dilakukan minimal seminggu sekali, dalam durasi minimal satu jam dalam seminggu. Kriteria khusus untuk kelompok lansia yang tidak melakukan aktivitas kognitif secara rutin adalah kriteria yang berkebalikan dari kriteria lansia yang rutin melakukan aktivitas kognitif.

Instrumen yang digunakan pada penelitian ini adalah 12 subtes fungsi kognitif, yang merupakan bagian dari baterai tes Neuropsikologi Indonesia yang dikembangkan oleh Radboud University Nijmegen, Unika Atma Jaya, dan Unika Soegiyapranata melalui Erasmus Grant Plus. Subtes-subtes yang mewakili keempat domain kognitif yang ada, yaitu atensi, memori, bahasa, dan fungsi eksekutif. Subtes-subtes yang mewakili domain atensi adalah stroop test, trail making test, dan bourdon test. Subtes-subtes yang mewakili domain memori adalah digit span (forward, backward, sequence), symbol span (forward, backward), RAVLT, Amsterdam Short Term Memory, visual reproduction test. Subtes-subtes yang mewakili domain bahasa adalah Boston Naming Test (BNT), token test, dan verbal fluency test. Subtes-subtes yang mewakili domain fungsi eksekutif adalah five point test.
Prosedur penelitian dimulai dengan mempersiapkan format informed consent (lembar persetujuan) untuk partisipan. Pada informed consent tersebut, peneliti akan memperkenalkan diri, menjelaskan tujuan penelitian, menginformasikan waktu yang diperlukan untuk berpartisipasi dalam penelitian ini, dan menyediakan data-data yang perlu diisi partisipan. Selain informed consent, peneliti juga mempersiapkan lembar data diri partisipan, yang berisi data-data demografi, sekaligus pertanyaan-pertanyaan yang berkaitan dengan aktivitas kognitif yang rutin dilakukan partisipan. Data tersebut akan digunakan untuk menentukan kelompok partisipan tersebut, kelompok rutin atau tidak rutin, juga mengetahui jenis aktivitas yang dilakukan partispan. Peneliti juga akan menanyakan riwayat penyakit, khususnya penyakit kronis kepada partisipan, serta durasi dideritanya penyakit tersebut. Pemilihan partisipan dapat dilakukan dengan memilih partisipan yang bersedia berpartisipasi dalam penelitian ini. Pemilihan partisipan juga akan dilakukan dengan menghubungi panti wreda yang ada di Jakarta. Peneliti akan mengajukan surat pengantar untuk memohon izin kepada pihak panti, dalam rangka pengambilan data penelitian ini.

Pada pelaksanaan pengambilan data, sebisa mungkin peneliti mengusahakan waktu dan tempat tes yang sesuai dan nyaman bagi partisipan. Tempat tersebut haruslah memungkinkan partisipan untuk dapat mendengar dengan jelas, melihat soal-soal maupun menjawab soal dengan nyaman, serta menulis jawaban atas tugastugas yang diberikan dengan jelas. Peneliti akan memilih tempat yang ada meja, dengan kursi yang tidak terlalu pendek, agar nyaman bagi partisipan dalam mengerjakan tes. Sementara itu, waktu 
yang akan dimanfaatkan peneliti untuk melaksanakan pengambilan data ini, adalah pagi hari. Akan tetapi, peneliti akan menanyakan kepada partisipan waktu yang nyaman, disesuaikan juga dengan kondisi rumah (misalnya, saat keadaan rumah sepi), ataupun kepada pengurus panti berkaitan dengan waktu yang tepat untuk melaksanakan tes. Setelah menyelesaikan semua tugas dalam pengambilan data ini, peneliti juga akan memberikan ucapan terima kasih berupa barang (reward) kepada partisipan.

Teknik statistik yang digunakan untuk mengolah data dari penelitian ini adalah uji beda dengan t-test two independent sample atau Mann-Whitney $U$ Test. Penggunaan teknik ini tergantung dari normal atau tidaknya distribusi data pada penelitian ini. Oleh karena ini peneliti juga melakukan uji normalitas dengan Saphiro Wilk dan Kolmogorov Smirnov. Selain itu, peneliti juga akan melakukan perhitungan nilai mean (ratarata) dari setiap subtes, pada masingmasing kelompok partisipan. Kemudian, norma kelompok penelitian ini juga akan dibuat.

\section{Hasil}

Data pada Tabel 1 merupakan gambaran data demografi partisipan pada penelitian ini. Skor rata-rata masing-masing subtes fungsi kognitif dari kedua kelompok partisipan dapat dilihat pada Gambar 1. Perbedaan skor rata-rata pada kedua kelompok, menunjukkan bahwa partisipan yang rutin melakukan aktivitas kognitif memiliki fungsi yang relatif lebih baik daripada kelompok partisipan yang tidak rutin melakukan aktivitas kognitif. Sementara itu, rendahnya skor rata-rata pada domain bahasa, khususnya pada fungsi pemahaman bahasa, menunjukkan bahwa secara umum lansia memiliki fungsi yang lemah dalam memahami katakata yang diucapkan orang lain. Sementara itu, pada kelompok partisipan yang tidak rutin melakukan aktivitas kognitif, ditemukan bahwa lansia memiliki fungsi yang lemah pada fungsi eksekutif, khususnya dalam hal fleksibilitas berpikir, kemampuan perencanaan, dan pengembangan metode baru. Partisipan pada kelompok ini akan lebih bersandar pada hal-hal yang telah ada sebelumnya, meniru ataupun mengulang cara-cara yang lama, dan akan kesulitan saat harus menciptakan sesuatu yang baru.

Sebelum melakukan uji beda, peneliti melakukan uji normalitas dengan berpatokan pada Saphiro Wilk dan Kolmogorov Smirnov. Hasil dari uji normalitas pada kedua kelompok partisipan ini yaitu persebaran data pada kedua kelompok sebagian besar tidak normal, sehingga peneliti memutuskan untuk menggunakan teknik uji beda dengan Mann-Whitney $U$ Test.

Sebelum melakukan uji beda, peneliti melakukan uji normalitas dengan berpatokan pada Saphiro Wilk dan Kolmogorov Smirnov. Hasil dari uji normalitas pada kedua kelompok partisipan ini yaitu persebaran data pada kedua kelompok sebagian besar tidak normal, sehingga peneliti memutuskan untuk menggunakan teknik uji beda dengan Mann-Whitney $U$ Test. 
Tabel 1.

Data Demografi Partisipan

\begin{tabular}{|c|c|c|c|c|c|c|}
\hline $\begin{array}{c}\text { Variabel } \\
\text { Demografis }\end{array}$ & $\begin{array}{c}\text { Partisipan yang } \\
\text { Beraktivitas } \\
\text { Kognitif } \\
(n=45)\end{array}$ & $\begin{array}{c}\text { Per- } \\
\text { sentase }\end{array}$ & $\begin{array}{c}\text { Partisipan yang } \\
\text { Tidak Berak- } \\
\text { tivitas Kognitif } \\
\quad(\mathrm{n}=45)\end{array}$ & $\begin{array}{c}\text { Per- } \\
\text { sentase }\end{array}$ & $\begin{array}{c}\text { Total } \\
\text { Partisipan } \\
(\mathrm{N}=90)\end{array}$ & $\begin{array}{c}\text { Per- } \\
\text { sentase }\end{array}$ \\
\hline \multicolumn{7}{|l|}{ Usia } \\
\hline - $61-64$ tahun & 5 orang & $11.11 \%$ & 6 orang & $13.33 \%$ & 11 orang & $12.22 \%$ \\
\hline - $65-74$ tahun & 33 orang & $73.33 \%$ & 20 orang & $44.44 \%$ & 53 orang & $58.89 \%$ \\
\hline - 75 - 84 tahun & 7 orang & $15.56 \%$ & 16 orang & $35.56 \%$ & 23 orang & $25.56 \%$ \\
\hline - > 85 tahun & - & - & 3 orang & $6.67 \%$ & 3 orang & $3.33 \%$ \\
\hline \multicolumn{7}{|l|}{ Status Pekerjaan } \\
\hline - Bekerja & 16 orang & $35.56 \%$ & 3 orang & $6.67 \%$ & 19 orang & $21.11 \%$ \\
\hline - Tidak Bekerja & 29 orang & $64.44 \%$ & 42 orang & $93.33 \%$ & 71 orang & $78.89 \%$ \\
\hline \multicolumn{7}{|l|}{ Jenis Kelamin } \\
\hline - Perempuan & 33 orang & $73.33 \%$ & 36 orang & $80 \%$ & 69 orang & $76.67 \%$ \\
\hline - Laki-laki & 12 orang & $26.67 \%$ & 9 orang & $20 \%$ & 21 orang & $23.33 \%$ \\
\hline \multicolumn{7}{|l|}{ Latar Belakang } \\
\hline - SMP - SMA & 23 orang & $51.11 \%$ & 36 orang & $80 \%$ & 59 orang & $65.56 \%$ \\
\hline - $\mathrm{D} 3-\mathrm{S} 2$ & 22 orang & $48.89 \%$ & 9 orang & $20 \%$ & 31 orang & $34.44 \%$ \\
\hline $\begin{array}{l}\text { Tinggal Bersama } \\
\text { - Keluarga Inti } \\
\text { - Keluarga bukan }\end{array}$ & 37 orang & $82.22 \%$ & 25 orang & $55.56 \%$ & 62 orang & $68.89 \%$ \\
\hline Inti & 3 orang & $6.67 \%$ & 1 orang & $2.22 \%$ & 4 orang & $4.44 \%$ \\
\hline - Sendiri & 2 orang & $4.44 \%$ & 4 orang & $8.89 \%$ & 6 orang & $6.67 \%$ \\
\hline - Panti & 2 orang & $4.44 \%$ & 15 orang & $33.33 \%$ & 17 orang & $18.89 \%$ \\
\hline \multicolumn{7}{|l|}{ Riwayat Penyakit } \\
\hline - Tidak Ada & 42 orang & $93.33 \%$ & 40 orang & $88.89 \%$ & 82 orang & $91.11 \%$ \\
\hline - Diabetes & 2 orang & $4.44 \%$ & 3 orang & $6.67 \%$ & 5 orang & $5.56 \%$ \\
\hline - Hipertensi & 1 orang & $2.22 \%$ & 2 orang & $4.44 \%$ & 3 orang & $3.33 \%$ \\
\hline
\end{tabular}




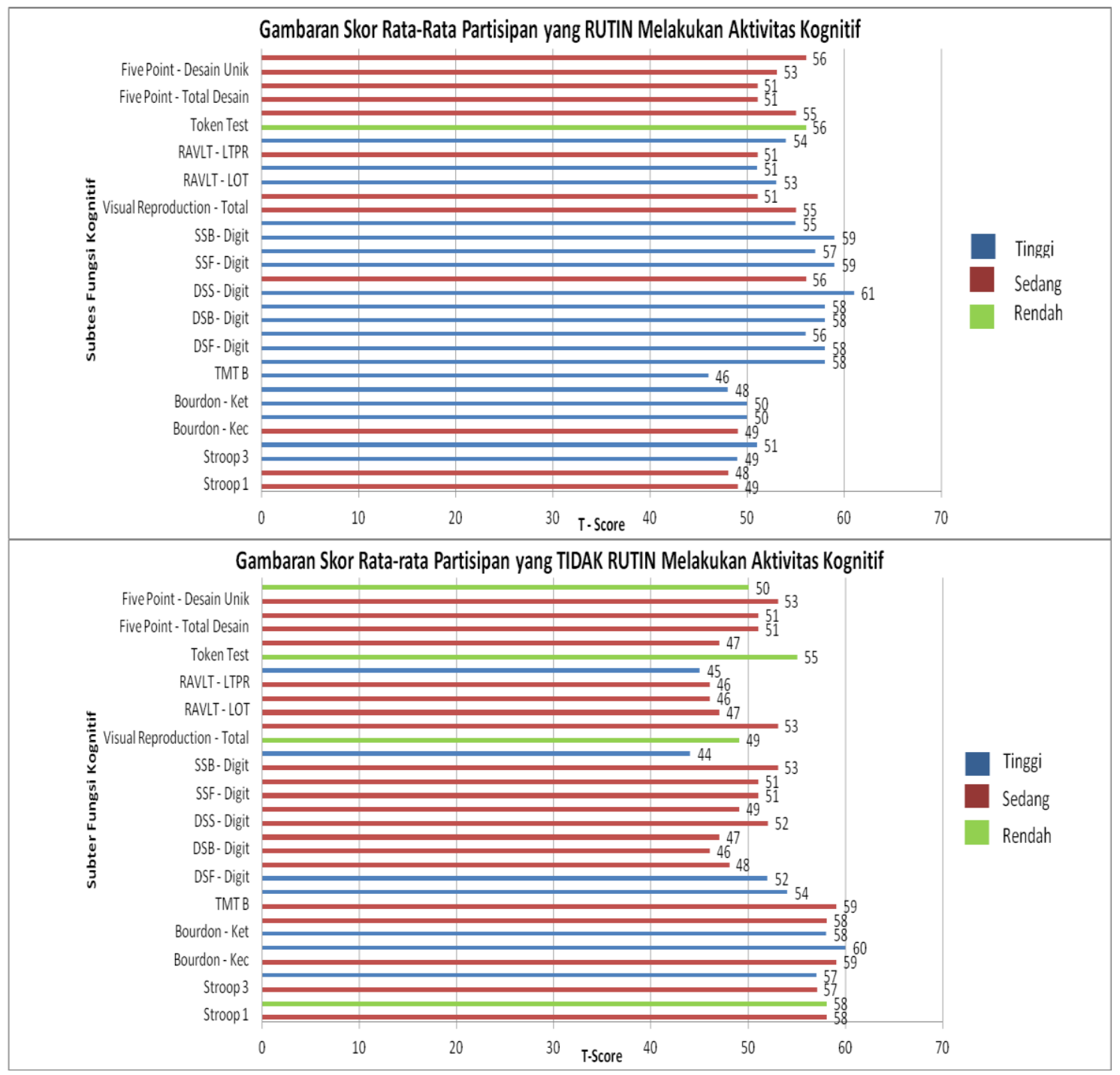

Gambar 1. Skor rata-rata fungsi kognitif pada kedua kelompok partisipan

Hasil uji beda dengan Mann-Whitney $U$ test menunjukkan hasil bahwa terdapat perbedaan yang signifikan pada semua domain fungsi kognitif. Namun, tidak terdapat perbedaan signifikan pada beberapa subtes, yaitu, subtes visual reproduction - waktu (domain memory), RAVLT - STPR (domain memory), subtes five point test - total desain, total desain benar, dan total desain unik (domain executive functioning). Lihat Tabel 2.

Selain uji beda yang dilakukan pada kedua kelompok berdasarkan aktivitas aktivitas kognitifnya, peneliti juga melakukan uji beda pada partisipan berdasarkan data demografi yang ada, yaitu berdasarkan usia, pendidikan terakhir, tinggal bersama, dan status pernikahan. Hasil dari uji beda tersebut adalah terdapat perbedaan signifikan pada beberapa subtes, yang dapat dilihat pada Tabel 3.

Data partisipan juga menunjukkan jenis aktivitas yang dilakukan oleh masing-masing kelompok partisipan. Gambar 2 dan 3 menunjukkan aktivitasaktivitas yang dilakukan kedua kelompok. 
Tabel 2.

Uji Beda Mann-Whitney U Test

\begin{tabular}{|c|c|c|c|c|}
\hline Domain & Subtes & Indikator & $\begin{array}{c}\text { Mann-Whitney } \\
\text { U Test }\end{array}$ & Asymp. Sig. \\
\hline \multirow{9}{*}{ Atensi } & \multirow[t]{4}{*}{ Stroop Test } & Tugas 1 & 553.5 & $.000^{*}$ \\
\hline & & Tugas 2 & 513.5 & $.000^{*}$ \\
\hline & & Tugas 3 & 595 & $.001^{*}$ \\
\hline & & Interference & 741 & $.028^{*}$ \\
\hline & Trail Making & Part A & 490 & $.000^{*}$ \\
\hline & Test & Part B & 330 & $.000^{*}$ \\
\hline & \multirow[t]{3}{*}{ Bourdon } & Kecepatan & 488 & $.000^{*}$ \\
\hline & & Konstansi & 541.5 & $.000^{*}$ \\
\hline & & Ketelitian & 745.5 & $.031^{*}$ \\
\hline \multirow{15}{*}{ Memory } & Digit Span & Total Benar & 654 & $.003^{*}$ \\
\hline & Forward & Total Digit & 666 & $.003^{*}$ \\
\hline & Digit Span & Total Benar & 541 & $.000^{*}$ \\
\hline & Backward & Total Digit & 513 & $.000^{*}$ \\
\hline & Digit Span & Total Benar & 537.5 & $.000^{*}$ \\
\hline & Sequence & Total Digit & 601 & $.001^{*}$ \\
\hline & Symbol Span & Total Benar & 496 & $.000^{*}$ \\
\hline & Forward & Total Digit & 509 & $.000^{*}$ \\
\hline & Symbol Span & Total Benar & 430.5 & $.000^{*}$ \\
\hline & Backward & Total Digit & 483 & $.000^{*}$ \\
\hline & \multicolumn{2}{|c|}{ Amsterdam Short Term Memory (ASTM) } & 458.5 & $.000^{*}$ \\
\hline & Visual & Total Skor & 552 & $.000^{*}$ \\
\hline & Reproduction & Waktu & 835.5 & .153 \\
\hline & RAVLT & STPR & 805 & .094 \\
\hline & & LTPR & 710.5 & $.014^{*}$ \\
\hline \multirow{4}{*}{ Language } & \multicolumn{2}{|c|}{ Boston Naming Test (BNT) } & 388.5 & $.000^{*}$ \\
\hline & \multicolumn{2}{|l|}{ Token Test } & 786.5 & $.031^{*}$ \\
\hline & \multicolumn{2}{|l|}{ Verbal Fluency } & 477 & $.000^{*}$ \\
\hline & Five Point Test & Total Desain & 874.5 & .265 \\
\hline Executive & & Total Desain Benar & 855 & .203 \\
\hline \multirow[t]{2}{*}{ Functioning } & & Total Desain unik & .928 & .495 \\
\hline & & Repetisi & 769.5 & .048 \\
\hline
\end{tabular}


Tabel 3.

Domain dan Subtes yang Berbeda Signifikan pada Data Demografi

\begin{tabular}{|c|c|c|c|c|c|}
\hline $\begin{array}{l}\text { Domain } \\
\text { Fungsi } \\
\text { Kognitif }\end{array}$ & Usia & $\begin{array}{c}\text { Pendidikan } \\
\text { Terakhir }\end{array}$ & Jenis Kelamin & $\begin{array}{c}\text { Status } \\
\text { Pernikahan }\end{array}$ & Tinggal Bersama \\
\hline Atensi & $\begin{array}{l}\text { Stroop 1,2,3 dan } \\
\text { TMT A \& B } \\
\text { digit span } \\
\text { (backward dan } \\
\text { sequence), symbol } \\
\text { span (forward dan } \\
\text { backward) }\end{array}$ & $\begin{array}{l}\text { Bourdon } \\
\text { konstansi, TMT } \\
\text { A\&B }\end{array}$ & $\begin{array}{l}\text { Bourdon } \\
\text { (konstansi), } \\
\text { TMT A \& B }\end{array}$ & $\begin{array}{l}\text { Stroop 1, } \\
\text { bourdon } \\
\text { (kecepatan). }\end{array}$ & $\begin{array}{l}\text { Stroop 1,2,3, bourdon } \\
\text { (kecepatan dan } \\
\text { konstansi), TMT A \& } \\
\text { B. }\end{array}$ \\
\hline Memori & $\begin{array}{l}\text { digit span } \\
\text { (backward dan } \\
\text { sequence), symbol } \\
\text { span (forward dan } \\
\text { backward) }\end{array}$ & $\begin{array}{l}\text { digit span } \\
\text { (backward), } \\
\text { symbol span } \\
\text { (forward dan } \\
\text { backward), ASTM, } \\
\text { visual } \\
\text { reproduction. }\end{array}$ & $\begin{array}{l}\text { visual } \\
\text { reproduction } \\
\text { (waktu), } \\
\text { RAVLT } \\
\text { (verbal } \\
\text { learning long } \\
\text { term) }\end{array}$ & $\begin{array}{l}\text { digit span } \\
\text { (forward), } \\
\text { ASTM. }\end{array}$ & $\begin{array}{l}\text { digit span (forward, } \\
\text { backward), symbol } \\
\text { span (forward, } \\
\text { backward), ASTM, } \\
\text { visual reproduction, } \\
\text { RAVLT (verbal } \\
\text { learning long term) }\end{array}$ \\
\hline Bahasa & $\begin{array}{l}\text { BNT dan verbal } \\
\text { fluency. }\end{array}$ & $\begin{array}{l}\text { BNT, token test, } \\
\text { verbal fluency. }\end{array}$ & $\begin{array}{l}\text { BNT, token } \\
\text { test }\end{array}$ & & BNT, verbal fluency. \\
\hline $\begin{array}{l}\text { Fungsi } \\
\text { Eksekutif }\end{array}$ & - & $\begin{array}{l}\text { Five point test } \\
\text { (total desain benar } \\
\text { dan repetisi). }\end{array}$ & $\begin{array}{l}\text { Five point } \\
\text { test (total } \\
\text { desain, total } \\
\text { benar, } \\
\text { repetisi). }\end{array}$ & & $\begin{array}{l}\text { Five point test (total } \\
\text { benar, desain unik). }\end{array}$ \\
\hline
\end{tabular}

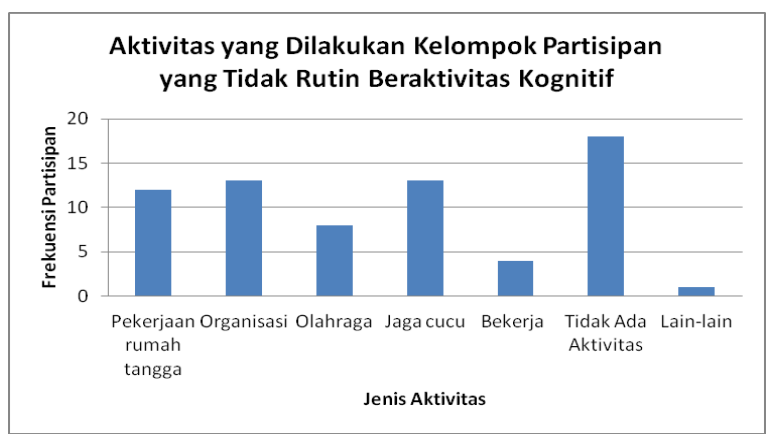

Gambar 2. Aktivitas kelompok rutin

\section{Diskusi}

Berdasarkan uji beda yang dilakukan pada kedua kelompok lansia, ditemukan bahwa terdapat perbedaan signifikan pada semua domain fungsi kognitif lansia yang

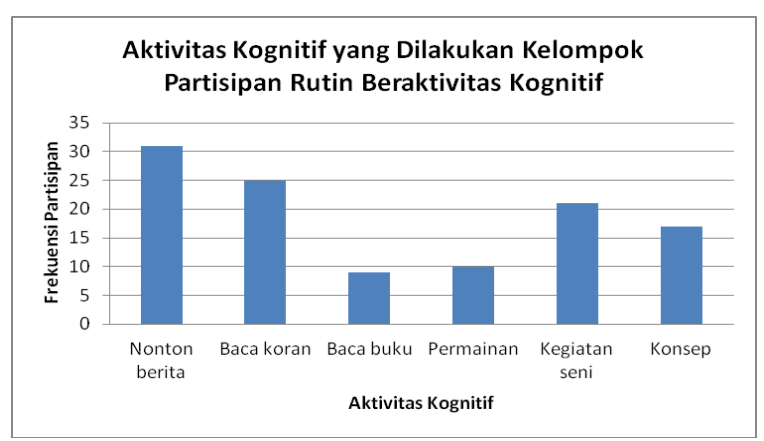

Gambar 3. Aktivitas kelompok tidak rutin

melakukan aktivitas kognitif secara rutin dan tidak rutin. Hal ini sejalan dengan penelitian yang telah dilakukan sebelumnya, seperti penelitian yang dilakukan Marquine et al. (2012), yang menunjukkan bahwa aktivitas kognitif yang dilakukan 
secara rutin berkaitan secara umum dengan fungsi kognitif lansia yang lebih tinggi. Wreksoatmojo (2015) juga menemukan bahwa lansia yang melakukan aktivitas kognitif memiliki fungsi kognitif yang relatif lebih baik daripada yang tidak. Sejalan dengan hal tersebut, Williams dan Kemper (2010) juga menyampaikan bahwa aktivitas yang menstimulasi kognitif dapat menjaga fungsi kognitif seseorang dengan lebih baik, saat mereka menua. Bielak (2010) juga menyatakan bahwa stimulasi kognitif yang rutin akan melatih otak, sehingga dapat mempertahankan fungsi kognitif yang prima. Ia bahkan menganalogikan bahwa otak manusia sama seperti otot. Saat seseorang ingin tetap mempertahankan fungsi yang baik pada ototnya, maka ia harus melatih ototnya secara rutin. Begitu juga dengan otak. Saat seseorang ingin mempertahankan fungsi kognitif yang tetap baik, maka aspek kognitifnya pun perlu distimulasi secara rutin.

Akan tetapi, dari 12 subtes yang mewakili 4 domain fungsi kognitif, terdapat beberapa subtes yang tidak berbeda secara signifikan, yaitu subtes dari domain memory (visual reproduction waktu dan RAVLT - STPR) dan semua subtes pada domain executive functioning. Tidak terdapatnya perbedaan signifikan pada subtes-subtes ini menunjukkan bahwa dalam menangkap, memproses, serta mempertahankan informasi yang bersifat visual, para lansia memiliki fungsi yang hampir sama, bahkan jika dilihat dari aktivitas yang dilakukan, baik lansia yang melakukan aktvitas kognitif dan tidak, sama-sama memiliki fungsi pemrosesan informasi visual yang cenderung menurun. Hal ini sejalan dengan hasil penelitian yang dilakukan oleh Leonards, Ibanez, dan Giannakopoulos (2002), tentang jenis stimulus yang memengaruhi memori. Dalam penelitian tersebut didapatkan hasil bahwa lansia lebih sulit mencerna informasi-informasi yang sifatnya visual (seperti wajah manusia) daripada mencerna informasi yang bersifat verbal. Leonards, et al. (2002) menambahkan bahwa hal ini mengindikasikan bahwa fungsi visual pada memori memang sensitif seiring dengan bertambahnya usia seseorang. Ditambah lagi dengan mulai melambatnya kecepatan pemrosesan informasi pada lansia, membuat lansia tidak dapat mencerna informasi visual tersebut dalam waktu yang cepat. Berdasarkan speed deficit hypothesis, penurunan fungsi working memory pada lansia merupakan hasil dari menurunnya kecepatan seseorang untuk memproses informasi (Whitbourne, 2003). Hilangnya memori tersebut dapat disebabkan oleh 2 mekanisme, yaitu waktu yang terbatas dan mekanisme yang berjalan simultan atau terus menerus (Whitbourne, 2003). Artinya, jika informasi yang datang dalam waktu yang cepat dan terus menerus, maka lansia akan mengalami kesulitan untuk mencernanya.

Selain itu, para lansia dari kedua kelompok kemungkinan memiliki kapasitas yang hampir sama juga dalam menyimpan informasi jangka pendek. Whitbourne (2003) menyatakan bahwa working memory merupakan kapasitas mental seseorang dan akan menjadi masuk akal jika usia semakin bertambah, maka terdapat penurunan juga pada pemrosesan serta penyimpanan informasi yang baru. Menurunnya fungsi pemrosesan informasi baru pada lansia, menyebabkan mereka tidak dapat menangkap dan menyimpan informasi dengan efektif, sehingga pada akhirnya mereka tidak dapat mengingat informasi tersebut dengan tepat juga (Whitbourne, 2003). 
Sementara itu, hasil penelitian ini menunjukkan bahwa kedua kelompok lansia, baik yang melakukan aktivitas kognitif secara rutin dan yang tidak, memiliki fungsi eksekutif yang cenderung sama (jika dilihat dari nilai rata-rata, maka berada pada kategori sedang cenderung rendah). Berdasarkan temuan pada penelitian ini, maka dapat disimpulkan bahwa lansia telah mengalami kesulitan untuk menciptakan sesuatu yang baru dan cenderung lebih mengikuti atau meniru hal-hal yang sudah ada saja. Fakta ini menunjukkan bahwa hasil penelitian ini sejalan dengan temuan sebelumnya. Secara umum otak akan mengalami pengurangan volume dan berat ketika usia bertambah. Frontal lobe, yang merupakan bagian otak yang mengontrol fungsi eksekutif, juga mengalami pengurangan tersebut (Hippel, 2007). Fungsi eksekutif meliputi kemampuan untuk merencanakan serta mengendalikan pikiran dan perilaku (Hippel, 2007). Zelinski, Dalton, dan Hindin (2011) juga menyampaikan bahwa fungsi eksekutif yang termasuk di dalamnya kemampuan untuk merencanakan, memonitor, mengaktifkan, mengubah, dan mengendalikan respon dan memanipulasi informasi, telah mengalami penurunan pada lansia. Fungsi eksekutif juga berkaitan dengan kreativitas seseorang. Whitbourne (2003) menyampaikan bahwa produktivitas serta kreativitas seseorang di masa tuanya, tergantung juga dari pengalaman pada masa muda. Individu yang memulai karir dengan mengeluarkan banyak ide dan menghasilkan karya, akan cenderung menjaga produktivitas juga saat mereka menua.

Pada semua kelompok usia, terlihat bahwa penurunan fungsi banyak terjadi pada domain atensi. Data ini menunjukkan bahwa pada masing-masing kelompok usia, mengarahkan fokus pada informasi tertentu dan mengabaikan informasi lainnya, merupakan sesuatu yang sulit bagi para lansia. Hal tersebut juga sejalan dengan pernyataan Santrock (2011), yang menyatakan bahwa lansia akan mulai mengalami penurunan dalam mencerna informasi secara cepat, dan cenderung untuk menghindari informasi yang tidak terlalu relevan. Whitbourne (2003) juga menyatakan bahwa lansia memiliki energi yang terbatas untuk mengarahkan sejumlah proporsi dari operasi mentalnya terhadap suatu informasi.

Sementara itu, dilihat dari pendidikan terakhir, yang dibagi menjadi sarjana dan tidak sarjana, terdapat perbedaan signifikan pada subtes-subtes tertentu di dalam 4 domain fungsi kognitif. Hal ini sejalan dengan penelitian-penelitian sebelumnya yang menyatakan bahwa tingkat pendidikan memengaruhi fungsi kognitif seseorang. Penelitian yang dilakukan Alvarado, Zunzunegui, Del Ser, dan Beland (2001) menyatakan bahwa jenjang pendidikan memengaruhi strategi kognitif seseorang. Lachman et al. (2009) juga menyatakan bahwa semakin tinggi pendidikan seseorang maka semakin mungkin seseorang terlibat dalam aktivitas-aktivitas yang menantang aspek kognitifnya. Aktivitas-aktivitas yang kompleks dan merangsang fungsi kognitif ditemukan juga dapat meningkatkan aspek-aspek kognitif seperti, fleksibilitas intelektual, yang berkaitan dengan fungsi eksekutif, memori, kefasihan berbahasa, serta visual-spasial (Williams dan Kemper, 2010). Hal ini juga terlihat dari temuan pada penelitian ini, bahwa kelompok lansia dengan latar belakang pendidikan sarjana ke atas, lebih unggul dalam kefasihan berbahasa dan mencerna memori visual, daripada kelompok lansia yang tidak sarjana. Sedangkan, subtes 
fungsi kognitif yang tidak berbeda secara signifikan berdasarkan tingkat pendidikan adalah beberapa subtes dari domain atensi, seperti stroop test, bourdon (kecepatan dan ketelitian). Temuan ini menunjukkan bahwa aspek atensi pada lansia telah mengalami penurunan secara umum. Lansia telah mulai sulit mengarahkan fokusnya pada suatu hal sementara banyak hal lain yang muncul. Hal ini juga sejalan dengan teori tentang attentional resources, yang menyatakan bahwa lansia memiliki energi yang terbatas untuk melakukan operasi kognitif, seperti fokus, mencerna, dan mengolah informasi (Whitbourne, 2003).

Hal lain yang dapat dibahas dalam bagian ini adalah mengenai hasil temuan lain dari penelitian ini. Pada penelitian sebelumnya yang dilakukan oleh Sims, Hosey, Levy, Whitfield, dan Katzel (2014) ditemukan bahwa dukungan sosial dari keluarga juga berkontribusi dalam perkembangan fungsi kognitif seseorang. Lansia yang mendapat dukungan sosial, khususnya dari keluarga, akan memiliki fungsi bahasa, abstraksi, spasial, dan memori yang cenderung baik. Pada penelitian ini, peneliti juga melakukan uji beda pada data partner tinggal para partisipan. Partner tinggal yang dimaksud disini adalah orang-orang yang tinggal bersama para partisipan. Berdasarkan hasil uji beda yang telah dilakukan sebelumnya, maka ditemukan terdapat perbedaan yang signifikan pada lansia berdasarkan partner tinggalnya, hampir dalam semua domain dari fungsi kognitif . Hal ini menunjukkan bahwa keberadaan orang-orang signifikan dalam kehidupan lansia sehari-hari juga memengaruhi perkembangan fungsi kognitifnya. Hasil penelitian ini dapat dikatakan sejalan juga dengan penelitian sebelumnya yang dilakukan Alvarado et al. (2014) bahwa ada perbedaan fungsi bahasa, khususnya verbal fluency, dan juga fungsi memori pada lansia berdasarkan partner tinggalnya. Pada penelitian ini juga terlihat bahwa partisipan yang rutin melakukan aktivitas kognitif lebih banyak tinggal dengan keluarga inti, seperti orang tua kandung dan anak kandung, serta keluarga bukan inti, seperti sepupu, paman, bibi, atau ipar. Sedangkan partisipan yang tidak rutin beraktivitas kognitif lebih banyak tinggal di panti dan sendiri. Hal ini menunjukkan bahwa keberadaan orang terdekat, figur signifikan, seperti keluarga, ada kemungkinan memengaruhi fungsi kognitif seseorang. Di Indonesia, peran keluarga merupakan hal yang penting. Saat seorang lansia sudah tidak bekerja, mereka cenderung akan bergantung pada anak atau anggota keluarga lainnya (Schroder-Butterfill \& Fithry, 2014). Sistem kekerabatan yang kental di Indonesia juga dapat menyebabkan ketergantungan lansia kepada anggota keluarga atau kerabat terdekat.

Uji beda berdasarkan status pernikahan juga terbukti menghasilkan adanya perbedaan yang signifikan pada fungsi kognitif lansia, khususnya pada domain atensi dan memory. Partisipan pada penelitian ini lebih banyak yang berstatus menikah dibanding lanjang dan bercerai. Akan tetapi, jika dicermati lebih dalam, jumlah partisipan yang menikah lebih sedikit pada kelompok yang tidak rutin melakukan aktivitas kognitif dibanding kelompok partisipan yang rutin. Sementara, partisipan yang berstatus lajang dan bercerai, justru lebih banyak pada kelompok partisipan yang tidak rutin beraktivitas kognitif. Hal ini menunjukkan bahwa kemungkinan keberadaan pasangan, yaitu suami atau istri, dan kondisi hubungan dengan pasangan, juga berdampak pada 
perkembangan fungsi kognitif seseorang. Penelitian sebelumnya yang dilakukan oleh Hakansson, et al., (2009) menunjukkan bahwa terdapat hubungan antara status pernikahan dengan fungsi kognitif pada masa tua. Penelitian tersebut juga menghasilkan kesimpulan bahwa individu yang tidak memiliki pasangan hidup akan berpotensi dua kali lebih besar mengalami gangguan kognitif dan Alzheimer's disease jika dibandingkan dengan individu yang memiliki pasangan hidup.

Jenis kelamin juga membedakan fungsi kognitif seseorang, khususnya pada konstansi kerja, atensi, bertahannya informasi visual maupun verbal, penalaran verbal, fungsi bahasa secara umum, dan kreativitas. Merino, Ruvalcaba, Merino, Contreras, dan Arias (2012) yang sebelumnya pernah melakukan penelitian mengenai prevalensi penuaan yang berhasil di Meksiko menyatakan bahwa laki-laki memiliki fungsi kognitif yang lebih baik daripada perempuan. Hal ini juga terkait dengan pendidikan yang ditempuh oleh laki-laki lebih tinggi dibanding perempuan. Hasil penelitian Maurer (2011) juga menunjukkan bahwa laki-laki memiliki waktu yang lebih lama untuk menempuh pendidikan, sehingga hasil skor kognitif pada laki-laki Amerika lebih tinggi daripada perempuan. Di Indonesia, belum banyak perempuan pada zaman dahulu yang memiliki kesempatan untuk menempuh pendidikan yang tinggi. Berdasarkan data yang peneliti peroleh dari partisipan dalam penelitian ini, cukup banyak partisipan perempuan yang berhenti sekolah ataupun bekerja saat sudah menikah. Mereka menyatakan bahwa mereka diminta untuk fokus mengurus anak dan keluarga oleh suami mereka. Fakta ini menunjukkan bahwa kemungkinan para perempuan yang akhirnya tidak bekerja dan lebih banyak di rumah, tidak banyak mendapat stimulasi kognitif, sehingga secara umum kemampuan kognitifnya cenderung tidak berkembang dan cenderung mampu melakukan hal-hal yang sudah biasa mereka lakukan saja.

Dalam penelitian ini, diperoleh data bahwa sebagian besar dari lansia, baik yang melakukan aktivitas kognitif secara rutin dan tidak rutin, memiliki pengalaman bekerja di kantor (seperti mengerjakan tugas-tugas administratif) dan profesional (seperti guru, dosen, dokter, penjahit, dan apoteker). Hal ini menunjukkan bahwa kedua kelompok lansia ini, sebenarnya memiliki latar belakang pekerjaan yang hampir sama. Akan tetapi, yang membedakan adalah jenis aktivitas yang dilakukan setelah berhenti bekerja. Sebagian besar lansia dari kelompok tidak rutin melakukan aktivitas kognitif tidak memiliki aktivitas yang rutin dan menstimulasi kognisinya. Hal ini dapat menyebabkan penurunan fungsi kognitif yang lebih cepat, dibandingan lansia yang masih melakukan aktivitas, khususnya aktivitas yang merangsang kognisi. Sementara itu, pada kelompok lansia yang rutin melakukan aktivitas kognitif, terdapat sebagian kecil lansia juga yang justru tidak memiliki pengalaman kerja sebelumnya. Akan tetapi, para lansia tersebut, masih melakukan aktivitas yang merangsang kognisi, sehingga fungsi kognitifnya terjaga. Data ini semakin menguatkan asumsi bahwa aktivitas yang merangsang kognisi seseorang dapat membuat fungsi kogntiif seorang terjaga.

Data demografi mengenai riwayat penyakit partisipan juga diperoleh dari penelitian ini. Jumlah partisipan yang memiliki riwayat penyakit ini lebih banyak pada kelompok lansia yang tidak 
aktif melakukan aktivitas kognitif secara rutin. Hal ini menunjukkan bahwa partisipan yang tidak melakukan aktivitas kognitif secara rutin kemungkinan disebabkan juga oleh riwayat penyakitnya. Cukierman-Yaffe (2014) menyatakan bahwa individu yang mengidap diabetes memiliki risiko yang lebih besar dalam pengembangan penyakit dementia dan gangguan kognitif. Diabetes yang berkaitan dengan disfungsi kognitif ini, bahkan dipertimbangkan untuk dianggap sebagai jenis lain komplikasi diabetes. Dalam penelitian ini, partisipan yang memiliki riwayat diabetes memiliki skor yang cenderung tinggi untuk memori jangka pendek, namun skor yang cenderung rendah pada memori jangka panjang. Hal ini sejalan dengan penelitian yang dilakukan Debling, Amelang, Hasselbach, dan Sturmer (2006) yang menghasilkan temuan bahwa diabetes berhubungan dengan fungsi kognitif yang rendah, khususnya dalam fungsi memori jangka panjang, tetapi tidak berkaitan dengan fungsi memori jangka pendek dan kefasihan berbahasa. Akan tetapi, pada penelitian ini, partisipan yang memiliki riwayat diabetes memiliki skor yang juga cenderung rendah pada kefasihan berbahasa.

Penyakit hipertensi juga berkaitan dengan fungsi kognitif seseorang. Adanya perubahan struktur dan aliran darah otak pada proses penuaan, kemungkinan menyebabkan disfungsi pada serebrovaskular dan dapat memengaruhi gangguan pada fungsi kognitif maupun perilaku seseorang. Penelitian yang dilakukan Gasecki, Kwarciany, dan Nyka (2013) menyebutkan bahwa hipertensi yang terkait dengan penurunan kognitif seseorang merupakan konsekuensi dari reorganisasi fungsi aliran darah dan kerusakan pembuluh darah otak yang saling memengaruhi.

Pada penelitian ini, peneliti menyadari adanya berbagai kekurangan. Peneliti menyadari adanya keterbatasan dalam memastikan kelompok partisipan dalam penelitian ini. Pada pelaksanaan pengambilan data kepada partisipan, peneliti meminta partisipan untuk memilih aktivitas kognitif yang rutin dilakukan oleh partisipan. Akan tetapi, peneliti tidak memberikan pilihan "lain-lain" yang memungkinkan partisipan untuk mengisi aktivitas kognitif lain yang mungkin dilakukan oleh partisipan. Hal ini menjadi keterbatasan dalam penelitian ini, karena ada kemungkinan partisipan melakukan aktivitas kognitif yang tidak ada dalam pilihan pada form isian partisipan.

\section{Kesimpulan}

Penelitian ini menghasilkan temuan bahwa aktivitas kognitif yang dilakukan secara rutin memberi kontribusi yang cukup penting bagi fungsi kognitif seseorang di masa tuanya. Aktivitasaktivitas yang merangsang kognisi perlu dilakukan rutin, bukan hanya sesekali saja. Lansia yang melakukan aktivitas kognitif secara rutin, memiliki fungsi kognitif yang relatif lebih baik daripada lansia yang tidak melakukan aktivitas kognitif secara rutin.

Pada masa tua, tidak dapat dipungkiri juga bahwa fungsi eksekutif seseorang akan mengalami penurunan. Seseorang akan lebih sulit untuk menciptakan hal-hal yang baru dan cenderung mengikuti ataupun mengulang cara-cara yang telah diketahui sebelumnya. Aktivitas kognitif juga tidak terbukti dapat meningkatkan fungsi eksekutif, khususnya fleksibilitas dan kreativitas berpikir lansia. Akan tetapi, aktivitas kognitif dapat berkon- 
tribusi pada fungsi memori dan atensi yang lebih baik pada lansia.

Selain aktivitas kognitif, kehadiran partner yang tinggal bersama lansia, status pernikahan, usia, pendidikan terakhir, jenis kelamin, dan riwayat penyakit pada lansia juga menjadi faktor yang dapat berpengaruh pada fungsi kognitif seseorang.

\section{Saran}

Berdasarkan hasil penelitian bahwa tidak adanya perbedaan signifikan pada aspek fungsi eksekutif kedua kelompok lansia, maka dapat dikatakan bahwa intervensi yang dilakukan tidak perlu terlalu berfokus pada cara merangsang kreativitas berpikir dan pemecahan masalah pada lansia lagi. Saran intervensi yang dapat dilakukan lebih mengarah kepada penurunan-penurunan fungsi di aspek yang lain, khususnya pada kelompok lansia yang tidak melakukan aktivitas kognitif secara rutin.

Saran untuk intervensi yang dapat dilakukan pada kelompok lansia yang tidak melakukan aktivitas kognitif secara rutin kemungkinan akan mengarah kepada hal-hal yang dikondisikan. Misalnya melakukan latihan otak kepada kelompok lansia ini, agar dapat menstimulasi kognitif lansia. Selain itu, pada penelitian ini kelompok lansia yang tidak melakukan aktivitas kognitif secara rutin kebanyakkan tinggal di panti wreda dan sudah tidak lagi tinggal bersama dengan keluarganya. Aktivitas-aktivitas latihan otak yang dilakukan secara rutin, seperti misalnya melakukan permainan yang berkaitan dengan memori visual maupun verbal, diharapkan dapat merangsang lansia agar dapat lebih produktif.

Saran yang juga dapat diberikan kepada pembaca yang hidup dengan lansia, maupun individu-individu yang akan memasuki masa lansia adalah melakukan aktivitas kognitif secara rutin. Hal ini tentu akan melatih dan mempersiapkan masing-masing individu dalam memasuki masa lansia nantinya.

\section{Kepustakaan}

Alvarado, B. E., Zunzunegui, M. V., Del Ser, T., \& Beland, F. (2001). Cognitive decline is related to education and occupation in a Spanish elderly cohort. Aging Clinical and Experimental Research, 14(2), 132-142.

Bielak, A. A. M. (2010). How can we not lose it if we still don't understand how to use it? Unanswered questions about the influence of activity participation on cognitive performance in older age. Gerontology, 56, 507-519. doi: 10.1159/000264918.

Cukierman-Yaffe, T. (2014). Diabetes as a disease of accelerated cognitive aging: Role of diabetes interventions and implications for patient care. Diabetes Manage, 4(1), 63 -69.

Debling, D., Amelang, M., Hasselbach, P., dan Sturmer, T. (2006). Diabetes and cognitive function in a populationbased study of elderly women and men. Journal of Diabetes and Its Complications, 20, 238-245. doi: 10.1016/j.jdiacomp.2005.06.016

Gasecki, D., Kwarciany, M., dan Nyka, W. (2013). Hypertension, brain damage, and cognitive decline. Current Hypertens Rep, 15, 547-558.

Geda, Y. E., Topazian, H. M., Lewis, R. A., Roberts, R. O., Knopman, D. S., Pankratz, V. S., Christianson, T. J. H., Boeve, B. F., Tangalos, E. G., Ivnik, R. J., \& Petersen, R. C. (2011). Engaging in cognitive activities, aging, and mild cognitive impairment: A population- 
based study. Journal of Neuropsychiatry and Clinical Neurosciences, 23(2), 149 154.

Hakansson, K., Ruvio, S., Helkala, E. L., Vilska, A. R., Winblad, B., Soininen, H., Nissinen, A., Mohammed, A. H., dan Kivipelto, M. (2009). Association between mid-life marital status and cognitive function in later life: Population based cohort study. BMJ, 339, 1-8, doi: 10.1136/bmj.b2462.

Haris, E. R., Steven, R., \& Handajani, Y. S. (2014). Kualitas hidup pada lansia dengan gangguan kognitif dan mental: Studi cross sectional di kelurahan Kalianyar, Jakarta Barat. Journal of Medicine, 13(2), 117 - 127.

Hippel, W. V. (2007). Aging, executive functioning, and social control. Current Directions in Psychological Science, 16(5), 240-244, doi: 10.1111/j.14678721.2007.00512.x.

Johansson, M. (2015). Cognitive impairment and its consequences in everyday life (Medical Dissertation). Faculty of Health Sciences, Linkoping University, Linkoping, Sweden.

Kamus Besar Bahasa Indonesia. (2018). Arti kata aktivitas. Diakses dari https://kbbi.web.id/aktivitas.

Kementerian Kesehatan Republik Indonesia. (2016). Situasi lanjut usia di Indonesia. Jakarta, Indonesia: Pusat Data dan Informasi.

Lachman, M. E., Agrigoroaei, S., Murphy, C., \& Tun, P. A. (2010). Frequent cognitive activity compensates for education differences in episodic memory. The American Journal of Geriatric Psychiatry, 18(1), 4-10.

Leonards, U., Ibanez, V., \& Giannakopoulos, P. (2002). The role of stimulus type in age related changes of visual working memory. Exp Brain Res,
146, 172-183. doi: 10.1007/s00221-0021175-9.

Lezak, D. M., Howieson, D. B., Bigler, E. D., \& Tranel, D. (2014). Neuropsychological assessment. New York: Oxford University Press.

Marquine, M. J., Segawa, E., Wilson, R. S., Bennett, D. A., \& Barnes, L. L. (2012). Association between cognitive activity and cognitive function in older hispanics. Journal of the International Neuropsychological Society, 18, 10411051.

Maurer, J. (2011). Education and malefemale differences in later-life cognition: International evidence from Latin America and the Caribbean. Demography, 48, 915-930, doi: 10.1007/s13524-011-0048-x.

Mella, N., Grob, E., Doll, S., Ghisletta, P., de Ribaupierre, A. (2017). Leisure activities and change in cognitive stability: A multivariate approach. Brain Science Journal, 7(27), 1-14, doi: $\underline{10.3390 / \text { brainsci7030027. }}$.

Merino, E. D. A., Ruvalcaba, N. M. M., Merino, M. J .A., Contreras, J. C., dan Arias, C. V. (2012). Prevalence of successful aging in the elderly in Western Mexico. Current Gerontology and Geriatrics Research, 2012, 1-6. doi: 10.1155/2012/460249.

Santrock, J. W. (2011). Live-span development. Thirteenth edition. New York: McGraw-Hill.

Schroder-Buterfill, E., \& Fithry, T. S. (2014). Care dependence in old age: Preferences, practices and implications in two Indonesian communities. Ageing \& Society, 34, 361-387, doi: $\underline{10.1017 / S 0144686 X 12001006 .}$

Sims, R. C., Hosey, M., Levy, S. A., Whitfield, K. E., \& Katzel, L. I. (2014). Distinct functions of social support 
and cognitive function among older adults. Experimental Aging Research, 40, 40-59.

Whitbourne, S. K. (2003). Adult development and aging: Biopsychosocial perspective. USA: John Wiley \& Sons.

Williams, K. N., \& Kemper, S. (2010). Interventions to reduce cognitive decline in aging. Journal of Psychosocial Nursing, 48(5), 42-51.

Wreksoatmaja, B. R. (2015). Aktivitas kognitif memengaruhi fungsi kognitif lanjut usia di Jakarta. CDK, 42(1), 7-13.

Zelinski, E. M., Dalton, S. E., dan Hindin, S. (2011). Cognitive changes in healthy older adults. Journal of The American Society on Aging, 35(2), 13-20. 